\title{
Hermeneutika Hans-Georg Gadamer dan Relevansinya terhadap Pemahaman Hadis "Keterlibatan Malaikat dalam Hubungan Seksual”
}

\author{
Nafisatul Mu'awwanah \\ UIN Sunan Kalijaga Yogyakarta \\ nafisatulmuawwanah243095@gmail.com
}

\begin{abstract}
This paper deals with Gadamer's hermeneutical theory and how relevant it is to the study of Islam, which in this case is applied in the hadith "the involvement of angels in sexual relations". The concept of Gadamer greatly emphasizes the merger of the horizons, the horizon of the text and the horizon of the reader. Merging the horizons will then generate meaningful sense. Meaningful sense is what according to Gadamer, can be applied in the reader. When Gadamer's hermeneutical theory is applied in the hadith of "the involvement of angels in sexual relations", a reader of hadith should be able to combine the horizon of the hadith, how it is understood in the time of the Prophet, and the horizon of the reader, the needs and conditions of the present. From the merger, it was found that the meaningful sense of the hadith is "keeping and maintaining harmony of husband and wife relationship". Meaningful sense of this hadith should be applied in the present, regardless of the nature of the relationship between husband and wife. So Gadamer's hermeneutical concept can be said to be relevant to eliminate the issues that develop today about gender bias.
\end{abstract}

Keywords: Hadith, Gadamer's Hermeneutical, Gender Justice, Meaningful Sense, Household Sexuality

\begin{abstract}
Abstrak
Tulisan ini membahas tentang teori hermeneutika Gadamer dan bagaimana relevansinya terhadap studi Islam, yang dalam hal ini diaplikasikan dalam hadis "keterlibatan malaikat dalam hubungan seksual”. Konsep Gadamer sangat menekankan kepada penggabungan horizon, yaitu horizon teks dan horizon pembaca. Penggabungan horizon tersebut selanjutnya akan menghasilkan Meaningful sense. Meaningful sense inilah yang menurut Gadamer, dapat diterapkan di masa pembaca. Ketika teori hermeneutika Gadaner diaplikasikan dalam hadis "keterlibatan malaikat dalam hubungan seksual", seorang pembaca hadis harus mampu menggabungkan horizon hadis, yaitu bagaimana hadis tersebut dipahami di masa Nabi, dan horizon pembaca, yaitu kebutuhan dan kondisi
\end{abstract}


Millatī, Journal of Islamic Studies and Humanities, Vol. 3, No. 2, Des. 2018: 277-299

masa kini. Dari penggabungan tersebut, ditemukan bahwa Meaningful sense dari hadis tersebut adalah "menjaga dan mempertahankan keharmonisan hubungan suami-istri". Meaningful sense dari hadis inilah yang harus diterapkan di masa kini, terlepas bagaimana bentuk dari sebuah hubungan antara suami-istri. Sehingga konsep hermeneutika Gadamer dapat dikatakan relevan untuk menghilangkan isu yang berkembang dewasa ini tentang bias gender.

Kata Kunci: Hadis, Hermeneutika Gadamer, Keadilan Gender, Meaningful sense, Seksualitas Rumah Tangga

\section{Pendahuluan}

Hermeneutika merupakan istilah yang pertama kali digunakan oleh kelompok studi teologis untuk menyebut sebuah kaidah dan aturan-aturan standar yang harus diikuti oleh seorang penafsir dalam memahami teks keagamaan, yang dalam perkembangannya juga terkait dengan segala hal yang bisa ditafsirkan. ${ }^{1}$ Problematika mendasar dalam mengkaji hermeneutika adalah problem penafsiran teks, baik teks keagamaan atau tidak, yang tentunya memiliki jarak historis dengan penafsir. Dengan begitu problem hermeneutika selalu berkaitan dengan proses pemahaman dan penerjemahan atas sebuah pesan yang disampaikan kepada masyarakat yang hidup dalam dunia yang berbeda, atau dalam bahasa Gadamer adalah sebuah pesan yang memiliki horizon atau cakrawala yang berbeda dengan cakrawala pembaca. ${ }^{2}$

Bukan berarti dua cakrawala yang berbeda dalam aktivitas memahami suatu teks tidak bisa disatukan. Menurut Gadamer, dua cakrawala yang berbeda tersebut dapat dikomunikasikan atau didialogkan, dengan menyemplungkan diri ke masa lalu yang disebutnya dengan peleburan cakrawala. Oleh karena itu pemahaman bukanlah soal memahami suatu objek, namun menemukan dan mencapai pemahaman di antara subjek dan objek. Tujuan dari mendialogkan dua cakrawala ini adalah untuk mendapatkan sesuatu yang universal yang lebih tinggi yang mampu melampau setiap partikularitas (tradisi yang berbeda-beda), sehingga yang universal inilah yang diterapkan di masa pembaca.

Di antara pesan yang memerlukan peleburan cakrawala untuk mendapatkan sesuatu yang universal adalah hadis tentang keterlibatan malaikat dalam

${ }^{1}$ Ahmalia dkk. Hermeneutika Transendetantal: Dari Konfigurasi Filosofis Menuju Praksis Islamic Studies, ed. Nafisul Atho' dan Arif Fahrudin (Yogyakarta: IRCiSoD, 2003), h. 18.

${ }^{2}$ Quraisy Shihab, Kaidah Tafsir (Tangerang: Lentera Hati, 2013), h. 401. 
hubungan seksual, atau jelasnya pelaknatan malaikat kepada istri yang menolak bersetubuh. Hadis tersebut disampaikan oleh Nabi di awal abad ketujuh yang pastinya cakrawalanya berbeda dengan cakrawala abad sekarang, yaitu abad ke-21. Untuk menerapkan di masa sekarang, diperlukan untuk menemukan sesuatu yang universal melalui peleburan cakrawala. Penerapan untuk hadis ini juga bertujuan untuk melihat seberapa jauh teori hermeneutika Gadamer mampu menjawab kebutuhan abad-21 yang menuntut hilangnya bias gender antara laki-laki dan perempuan.

\section{Pemikiran Hermeneutika Hans Georg Gadamer}

Hans-Georg Gadamer ${ }^{3}$ adalah seorang filosof yang terkemuka di bidang hermeneutik. Hal ini tidak terlepas dari karyanya yang sangat penting, yaitu Wahrheit und Methode, yang membuatnya berpengaruh tidak hanya di Dunia Barat, namun juga telah memasuki Dunia Timur, terutama pada ilmuanilmuan yang mendalami filsafat secara umum, dan teori-teori penafsiran secara khusus. ${ }^{4}$ Pemikirannya dilatarbelakangi oleh fenomenologi, dan ketertarikannya

${ }^{3}$ Hans-Georg Gadamer lahir di Marburg pada tahun 1900. Ia adalah seorang filosof jerman. Ia sempat menimba ilmu di Breslau, tetapi kemudian kembali ke kota kelahirannya untuk belajar filsafat kepada para filosof Neo-Kantinian, yakni Paul Natorp dan Nicolai Hartman. Ia mampu meraih gelar doktornya di usia 22 tahun di tahun 1922, kemudian menjadi dosen privat di Marburg dan menjadi professor di tahun 1937. Sejak tahun 1939 ia pindah ke Leipzig dan kemudian ke Frankfurt am Main di tahun 1947. Setelah itu dari tahun 1949 ia mengajar di Heidelberg sampai pension. Ayahnya adalah seorang yang ahli akan ilmu kealaman yang juga sempat menjadi rector Universitas Marburg. Sebagai ayah yang mempunyai disiplin ketat dan akademisi terpandang, ia menginginkan anaknya mengikuti jejaknya sebagai ilmuan eksak. Di lain pihak Gadamer semenjak menempuh pendidikan dasar dan menengahnya menunjukkan minat yang bersebrangan dengan ayahnya. Dia lebih tertarik apa yang dikenal dengan ilmuilmu humaniora, khususnya sastra dan filologi. Walaupun tetap meluluskan anaknya belajar humaniora, namun kekhawatiran ayahnya wajar jika dikaitkan dengan kondisi masyarakat Jerman ketika itu. sKetika itu semangan modern berada di titik balik, teknologi menjadi dewa serta teknik menjadi keyakinan umum. Selama hidupnya Gadamer telah menjalani berbagai peristiwa penting abad 20, diantaranya adalah Revolusi Bolshevik di Rusia, dan dua Perang Dunia, terbelahnya Jerman menjadi dua blok, Keruntuhan Tembok Berlin, dan yang paling akhir adalah Peristiwa 11 September 2000. Adapun pemikirannya banyak dipengaruhi oleh Heideger dan hal inilah yang membuatnya jauh dari pengaruh-pengaruh Neo-Kantinisme. Banyak tulisannya yang memberikan interpretasi tentang filosof-filosof masa lampau, seperti Plato, Herder, dan Hegel. Lihat dalam Ahmalia dkk. Hermeneutika Transendetantal..., h. 132.

${ }^{4}$ Sahiron Syamsuddin, Hermeneutika dan Pengembangan Ulumul Qur'an (Yogyakarta: Pesantren Nawesea Press, 2009), h. 43. 
Millatī, Journal of Islamic Studies and Humanities, Vol. 3, No. 2, Des. 2018: 277-299

kepada ilmu-ilmu sosial dan humaniora. ${ }^{5}$ Berikut adalah gambaran umum dari pemikiran dan teori hermeneutika yang dikembangkan oleh Gadamer;

\section{Kritik atas Kebenaran dan Metode}

Melalui karyanya Wahrheit und Methode_yang diterjemahkan ke dalam bahasa Inggris Truth and Method dan dalam bahasa Indonesia Kebenaran dan Metode_ Gadamer menawarkan sebuah pemahaman hermeneutik yang berbeda dengan pemahaman sebelumnya. Gadamer mencoba menghindarkan hermeneutik dari bias-bias objektivisme modern, yang terletak pada dua kata kunci, yaitu kebenaran dan metode. Sebelum Gadamer, diskursus hermeneutika tak terpisahkan dengan dunia positivisme dan disatukan dengan sains yang bersifat metodologis serta bertujuan mendapatkan kebenaran yang objektif. ${ }^{6}$

Persoalan pertama yang dikritik adalah persoalan 'kebenaran' dalam hermeneutik. Setiap model penjelasan ilmiah bertujuan untuk mencarikan kebenaran yang valid, yang diistilahkan dengan kebenaran ilmiah. Apapun yang tidak sesuai dengan kebenaran ilmiah adalah tidak relevan. Menurut Descartes, kebenaran adalah sesuatu yang jika sekali diperoleh tidak akan bisa diragukan lagi, atau kebenaran harus mencapai tingkat kepastian seperti dalam matematika. ${ }^{7}$ Menurut Gadamer, prinsip kebenaran yang objektivis memang bisa diberlakukan dalam ilmu-ilmu alam, karena basis ilmu alam adalah logika matematis dan mendasarkan diri pada pengertian kebenaran korespondensi. Namun, hermeneutika sebagai ilmu humaniora (kemanusiaan) kebenarannya tidak bisa dibakukan dan dibekukan seperti dalam matematika. Menurut Gadamer, sebagai ilmu humaniora, hermeneutika tidak bisa dilepaskan begitu saja dari entitas pengarang dan penafsir yang tentu memiliki wilayah historisitasnya sendiri. Ia menggagas suatu bentuk baru dari objektivitas yang didasarkan pada kenyataan bahwa apa yang diperoleh membentuk sesuatu pemahaman yang menghadirkan dirinya sendiri. ${ }^{8}$

Kebenaran dalam hermeneutik menurut Gadamer adalah kebenaran yang sarat makna (Meaningful sense) yang dapat menolong manusia menjadi lebih manusiawi, yang pastinya bergerak sesuai dengan gerak manusia pengamat.

${ }^{5}$ Ahmalia dkk. Hermeneutika Transendetantal..., h. 132.

${ }^{6}$ Hans-Georg Gadamer, Kebenaran dan Metode, terj. Ahmad Sahidah (Yogyakarta: Pustaka Pelajar, 2010), h. Vi.

${ }^{7}$ Inyiak Ridwan Muzir, Hermeneutika Filosofis Hans-Georg Gadamer, h. 20.

${ }^{8}$ Hans-Georg Gadamer, Kebenaran dan Metode, h. 21. 
Dalam ilmu-ilmu humaniora, kebenaran bergerak sesuai dengan gerak manusia pengamat dan manusia yang diamati dalam lintasan ruang dan waktu. ${ }^{9}$ Dan kebenaran objektif yang tidak bisa diragukan dan tidak bisa dirubah dalam hermeneutika, menurut Gadamer, mustahil untuk didapatkan.

Dalam diskursus hermeneutik sebelum Gadamer, kebenaran yang objektif hanya dapat diperoleh melalui metodologi tertentu, yang selanjutnya persoalan metode inilah yang menjadi kritik Gadamer. ${ }^{10}$ Keinginan untuk setara dengan ilmu-ilmu alam secara epistemologis justru membuat ilmu-ilmu tentang manusia (humaniora) memperlakukan tradisi yang semestinya dialami secara hermeneutis, malah diperlakukan sebagai objek yang harus didekati dengan metode yang rigid agar kebenaran yang pasti tentangnya dapat ditemukan. Menurut Gadamer, ilmu-ilmu tentang manusia seharusnya secara hermeneutis mengalami sebuah tradisinya, yang semata bukanlah serangkaian peristiwa yang akan diketahui, namun merupakan ekspresi yang akan dipahami. Tradisi-tradisi historis mengekspresikan dirinya sebagai yang ingin dipahami. ${ }^{11}$

Akibat dari pemikiran Gadamer ini adalah bahwa hermeneutika tidak bisa didekati hanya dengan metodologi, karena akan melepaskan dari berbagai kecenderungan dan keinginan subjektif pengalaman kekinian. Persoalan Untuk memahami karya masa lalu bukan metodologi yang diperlukan tetapi pengalaman yang menyeluruh di alam semesta. Dalam ilmu-ilmu kemanusiaan yang diutamakan adalah apa yang akan dilihat dengan metode, bukan pembahasan mengenai metode yang dapat mengantarkan kepada kebenaran yang pasti. ${ }^{12}$ Jika yang didekati telah dikenal, diakrabi, dan dipahami, tentu persoalan metode tidak menentukan lagi, karena tujuan dari ilmu-ilmu manusia pada akhirnya adalah bagaimana memahami manusia yang hidup dalam tradisi, bukan memanipulasinya, merekayasa, atau menguasainya. ${ }^{13}$ Dengan demikian bagi Gadamer, verifikasi metodologis atau hukum umum yang menaungi segala sesuatu menjadi soal nomor dua. Menurutnya, soal pertama yang mesti didudukkan adalah apa saja syarat bagi pemahaman. Dengan kata lain yang ditekankan oleh Gadamer adalah 'bagaimana saya dapat memahami sesuatu'.

\footnotetext{
${ }^{9}$ Ibid., h. 26.

${ }^{10}$ Ibid., h. 3.

${ }^{11}$ Ibid., h. 325.

${ }^{12}$ Nasr Hamid Abu Zayd, Al Quran hermeneutic, h. 71.

${ }^{13}$ Hans-Georg Gadamer, Kebenaran dan Metode, h. 325.
} 
Millatī, Journal of Islamic Studies and Humanities, Vol. 3, No. 2, Des. 2018: 277-299

\section{Konsep Hermeneutika Gadamer}

Kritik yang dilontarkan oleh Gadamer yang melahirkan hermeneutika filosofis dan menekankan pengalaman sebagai titik tolaknya, melahirkan beberapa konsep penting perihal pengalaman secara umum dan kaitannya dengan apa yang dialaminya, yang dengannya kebenaran dalam pandangan Gadamer (Meaningful sense) dapat diperoleh. Berikut adalah konsep-konsep yang ditekankan oleh Gadamer dalam sebuah pemahaman atau interpretasi;

Pertama, adalah konsep prasangka dan tradisi..$^{14}$ Sebagaimana yang telah disinggung sebelumnya, bahwa menurut Gadamer, hermeneutik tidak bisa dilepaskan begitu saja dari entitas penafsir yang sebelumnya telah memiliki prasangka. Hal ini dikarenakan seorang penafsir selalu terikat dengan konteks tradisi tempat penafsir, sebagai pembagian atas prasangka-prasangka dasar dan pemahaman.

Ketika seseorang ingin memahami sebuah teks, pastinya diawali oleh sensitivitas akan kebaruan teks, bahwa teks itu ingin mengatakan sesuatu kepadanya. Sensitivitas ini muncul pastinya bukan dari kenetralan atau kekosongan diri dari pembaca, melainkan asimilasi sadar atau prasangka-prasangka penafsir tersebut. Dengan menempatkan dalam tradisinya, interpretator dapat memainkan prasangka-prasangkanya sendiri dalam menilai teks dan kebenaran.

Namun, prasangka dipandang oleh Gadamer berpotensi mengandung sisi positif sekaligus negatif namun perlu direhibilitasi. Dengan adanya rehibilitasi, akan mampu membedakan prasangka yang legitimet dengan yang tidak. Dengan merujuk pada pembagian yang dilakukan pencerahan, prasangka terbagi atas prasangka otoritas_yaitu prasangka yang mendasarkan pada otoritas di luar diri seseorang_dan prasangka ketergesaan_yaitu prasangka yang terburu-buru tanpa menggunakan rasio, maka prasangka yang legitimet adalah prasangka yang tidak terburu-buru. ${ }^{15}$

${ }^{14}$ Gadamer membangun konsep ini di atas kedua eksposisi mengenai fore-structure pemahaman Heidegger dan penekanan Bultmann terhadap pra-pemahaman, yang pertama direalisasikan dan yang kedua diperlebar menjadi konsep "prasangka” yang merupakan sebuah "cakrawala pemahaman". Sebelumnya, adanya prasangka ini dianaktirikan oleh ilmu pengetahuan modern. Yang dinginkan dalam prinsip-prinsip pengetahuan modern adalah kondisi pemahaman yang murni yang tidak terpengaruh oleh apapun di luar subjek. Prasangka memperoleh pengertian negatif oleh pengetahuan modern, karena dipandang sebagai putusan yang tidak berdasar. Sedangkan dasar yang patut dijadikan landasan adalah dasar yang rasional. Lihat dalam Hans-Georg Gadamer, Kebenaran dan Metode..., h. 328.

${ }^{15}$ Inyiak Ridwan Muzir, Hermeneutika Filosofis Hans-Georg Gadamer (Yogyakarta: ar-Ruzz Media, 2010), h. 132. 
Dengan memandang prasangka seperti ini, akan sampai kepada peran tradisi dalam penelitian historis. Cara menerima yang seperti ini, membuat tradisi tidak hanya menjadi objek mati untuk diteliti, namun juga memotivasi dan mengarahkan penelitian sejarah. ${ }^{16}$ Artinya, kesadaran akan prasangka dan tradisi yang melingkupi penafsir masa sekarang, menyadarkan pula akan adanya prasangka dan tradisi yang mempengaruhi penulisan teks dalam sejarah. Hakekat sejarah adalah kesatuan sejarah dengan pemahaman tentangnya, dan inilah yang disebut oleh Gadamer dengan keterpengaruhan oleh sejarah (wirkungsgeschichte). ${ }^{17}$

Kedua, adalah konsep kesadaran akan sejarah berdampak (wirkungsgeschichtliches bewusstsein) dan peleburan cakrawala. Wirkungsgeschichte adalah realitas sejarah (tradisi, kultur, atau pengalam hidup) yang merupakan tempat sejarah terealisasi (kontek di mana teks masa lalu ditulis). ${ }^{18}$ Dalam teori ini, penafsir menemukan dirinya dalam "situasi"-nya sendiri di mana ia harus memahami teks melalui prasangka-prasangka yang diperolehnya. Dan ketika ingin memahami sebuah fenomena yang memiliki jarak historis dengannya, mau tidak mau penafsir harus menyadari akan keterpengaruhan realitas sejarah terhadap teks masa lalu.

Selanjutnya realitas sejarah yang berpengaruh tersebut membentuk sebuah "cakrawala" yang membuatnya menjadi historis dan terbatas. Cakrawala mempunyai makna bahwa setiap pemikiran mesti terikat dengan ditermanisasinya yang terbatas. Sehingga sebuah fenomena masa lalu memiliki cakrawala tersendiri yang berbeda dengan cakrawala sekarang. Dan perlu disadari juga di mana kita yang memahami masa lalu juga dipengaruhi oleh tradisi sekarang, yang pastinya membentuk cakrawala tersendiri yang berbeda dengan cakrawala historis. ${ }^{19}$ Bukan berarti dua cakrawala yang berbeda dalam aktivitas memahami masa lalu tidak bisa disatukan. Namun, dua cakrawala tersebut dapat dikomunikasikan atau didialogkan. Tujuan dari mendialogkan dua cakrawala ini adalah untuk mendapatkan sesuatu yang universal yang lebih tinggi yang mampu melampau setiap partikularitas (tradisi yang berbeda-beda). Dari sinilah kebenaran dalam pandangan Gadamer (Meaningful sense) dapat diperoleh. Proses inilah yang disebut dengan peleburan cakrawala. ${ }^{20}$

\footnotetext{
${ }^{16}$ Ibid., h. 134.

${ }^{17}$ Ibid., h. 137.

${ }^{18}$ Hans-Georg Gadamer, Kebenaran dan Metode, h. 363.

${ }^{19}$ Hans-Georg Gadamer, Kebenaran dan Metode, h. 365.

20 Sebuah pemahaman telah tercapai ketika mencapai peleburan cakrawala. Cakrawala kita berada dalam sebuah proses formasi berlanjut dengan menguji prasangka-prasangka kita
} 
Millatī, Journal of Islamic Studies and Humanities, Vol. 3, No. 2, Des. 2018: 277-299

Dalam peleburan ini, dituntut adanya "permainan" antara sejarawan masa sekarang dengan peristiwa sejarah masa lalu. Seorang sejarawan tidak diarahkan untuk memahami maksud author dan tidak pula dikendalikan oleh kepentingan-kepentingan masa sekarang. Ketika keduanya melebur dalam arena "permainan", untuk memahami masa lalu yang diperlukan bukan lagi mengambil jarak dengan objek, namun justru menyemplungkan diri ke objek atau masa lalu. Hal ini dikarenakan dalam ilmu sejarah, untuk memahaminya perlu mencapai kesepahaman antara dua horizon, yaitu horizon masa lalu dan masa kini. Sehingg masa lalu tidak diperlakukan sebagai objek dalam dirinya sendiri, akan tetapi dipahami dalam hubungannya dengan masa sekarang. ${ }^{21}$

Ketiga, adalah konsep pengalaman hermeneutis. Kesadaran akan keterpengaruhan oleh sejarah, kemudian membentuk sebuah horizon, mendorong agar kita menyadari bahwa setiap pemahaman terikat oleh situasi tertentu, dan kesadaran bahwa situasi kita juga ikut mewarnai pemahaman ketika kita menafsirkan fenomena sejarah. Hal ini berdampak pada kesadaran akan perlunya pemahaman baru ketika situasi berubah, dan pemahaman kita dalam situasi sekarang juga dimungkinkan akan terjadi perubahan ketika situasi berubah pula. ${ }^{22}$ Inilah yang disebut sebagai pengalaman hermeneutik.

Pengalaman harus dipahami sebagai proses, bukan sebagai suatu tujuan. Oleh karenanya ia terbuka terhadap pengalaman-pengalaman baru, ketika dihadapkan dengan tradisi yang baru pula. Jadi pengalaman hermeneutik yang didasari akan keterpengaruhan tradisi, berdampak membuka diri terhadap tradisi

dalam memasuki masa lalu dan berusaha memahami bagian-bagian dari tradisi kita. Kesadaran akan sejarah berdampak menolong kita dalam mengontrol peleburan cakrawala. Oleh karena itu pemahaman bukanlah soal memahami orang lain, namun menemukan dan mencapai pemahaman di antara kedua belah pihak. Adanya jarak menyebabkan terjadi proses mediasi, integrasi, dan asimilasi antara yang lalu dengan yang kini, dan pemahaman menjadi suatu yang produktif. Karenanya mampu menyisihkan prasangka yang benar dari yang keliru. Atau dapat dikatakan, melalui peleburan ini prasangka yang legitimate akan terwujud. Lihat dalam Inyiak Ridwan Muzir, Hermeneutika Filosofis Hans-Georg Gadamer..., h. 141.

${ }^{21}$ Untuk melihat cakrawala historis_yang nantinya akan dikomunikasikan dengan cakrawala pembaca_diperlukan usaha khusus, sebab bagaimana cara kita melihat sesuatu pasti dipengaruhi oleh apa yang paling dekat dengan kita (kecenderungan). Oleh karenanya, menurut Gadamer, hendaknya jangan tergesa-gesa dalam mengkonstruksi masa lalu melalui pemahaman makna dalam diri kita. Dibutuhkan kesabaran dan ketelatenan tersendiri agar makna masa lalu bisa dilihat di masa sekarang. Kesabaran dan ketelatenan adalah dalam persoalan memilah dan memilih. Hal ini juga perlu menyelidiki pra-sejarah dan pasca sejarah dimana sejarah itu terjadi. Lihat dalam Hans-Georg Gadamer, Kebenaran dan Metode, h. 124.

${ }^{22}$ Ibid., h. 363. 
baru. Inilah yang menjadi prinsip pengalaman hermeneutik sesungguhnya. ${ }^{23}$ Kesadaran hermeneutik adalah kesadaran akan keterbukaan untuk mengalami. Hal ini menunjukkan bahwa sebuah pengalaman baru tidak sekedar mengimplikasikan robohnya yang pertama, namun merepresentasikan sebuah pengetahuan baru, kita tidak hanya mengetahui lebih banyak, melainkan lebih baik. Pengalaman ini adalah sebuah kesadaran yang tidak akan menjadikannya baku dan bersifat selamanya. ${ }^{24}$

Keempat, adalah konsep penerapan atau aplikasi. Menurut Gadamer, pemahaman selalu melibatkan penerapan atau aplikasi sebuah teks ke dalam situasi penafsir. Persoalan aplikasi adalah persoalan bagimana pemahaman terhadap masa lalu memberi tahu tentang sesuatu yang seharusnya dilakukan di situasi partikular. Jadi hal ini berkaitan dengan bagaimana menerapkan yang diperoleh dari pemahaman masa lalu kepada situasi khusus orang yang memahaminya. ${ }^{25}$

Pertanyaannya adalah sesuatu atau pemahaman apakah yang bisa diterapkan di situasi pembaca? Untuk menjawabnya Gadamer terlebih dahulu merujuk kepada pendapatnya Aristoteles tentang phronesis, yang didefinisikan sebagai pengetahuan moral tertinggi atau pengetahuan tentang "yang baik". Apa "yang baik" ini adalah sesuatu yang umum atau universal, sementara plilaku yang dinilai sebagai baik dan buruk adalah sesuatu yang khusus. ${ }^{26}$ Keumuman atau keuniversalan ini terletak pada fakta bahwa dia akan selalu dipahami dengan cara yang berbeda. Artinya pengetahuan yang universal ini akan berdampak secara berbeda menurut keragaman situasinya. Dan ini hanya bisa dipahami jika dimediase dengan suatu perbuatan yang khusus dan kongrit. ${ }^{27}$ Pemahaman yang universal dalam bahasa Gadamer adalah meaning ful sense (makna yang berarti),

${ }^{23}$ Richard E. Palmer, Hermeneutika Teori Baru, h. 247.

${ }^{24}$ Keterbukaan ini mungkin karena pengalaman hermeneutik mengandung kesadaran akan keterpengaruhan sejarah atau tradisi yang membiarkan dirinya terbuka dengan klaim kebenaran baru dan bersifat terbatas. Jika setiap pembaca memiliki tradisi atau situasi yang berbeda, maka pemahaman terhadap teks juga akan berbeda. Oleh karenanya sebuah teks dapat dikatakan sudah dipahami jika ia dipahami secara berbeda oleh pembacanya sesuai dengan perbedaan tradisi atau ruang dan waktu. Atau dapat dikatakan sebuah pemahaman terhadap suatu teks itu bersifat terbuka. Lihat dalam Inyiak Ridwan Muzir, Hermeneutika Filosofis HansGeorg Gadamer, h. 146.

${ }^{25}$ Hans-Georg Gadamer, Kebenaran dan Metode, h. 370.

${ }^{26}$ Ibid., h. 375.

${ }^{27}$ Inyiak Ridwan Muzir, Hermeneutika Filosofis Hans-Georg Gadamer, h. 154. 
Millatī, Journal of Islamic Studies and Humanities, Vol. 3, No. 2, Des. 2018: 277-299

atau pesan yang lebih berarti dari pada sekedar makna literar. ${ }^{28}$

Dari sini dapat disimpulkan, bahwa kebenaran yang menjadi kepeduliannya adalah kebenaran yang sarat makna (Meaningful sense) yang dapat menolong manusia menjadi lebih manusiawi, atau yang berarti bagi kehidupan manusia pembaca. Dengan demikian bagi Gadamer verifikasi metodologis yang mampu menaungi segala sesuatu, menjadi soal nomor dua. Menurutnya, soal pertama yang mesti didudukkan adalah apa saja syarat kemungkinan bagi pemahaman. Dengan ungkapan lain, yang diperlukan adalah 'bagaimana saya dapat memahami sesuatu?' Di sinilah diperluhkan dengan apa yang disebutnya dengan penguasaan pengalaman. Kebenaran ini hanya mampu diperoleh melalui peleburan dua cakrawala, yaitu pengalaman teks dan pengalaman pembaca. Singkatnya dapat dilihat dalam tabel di bawah ini.

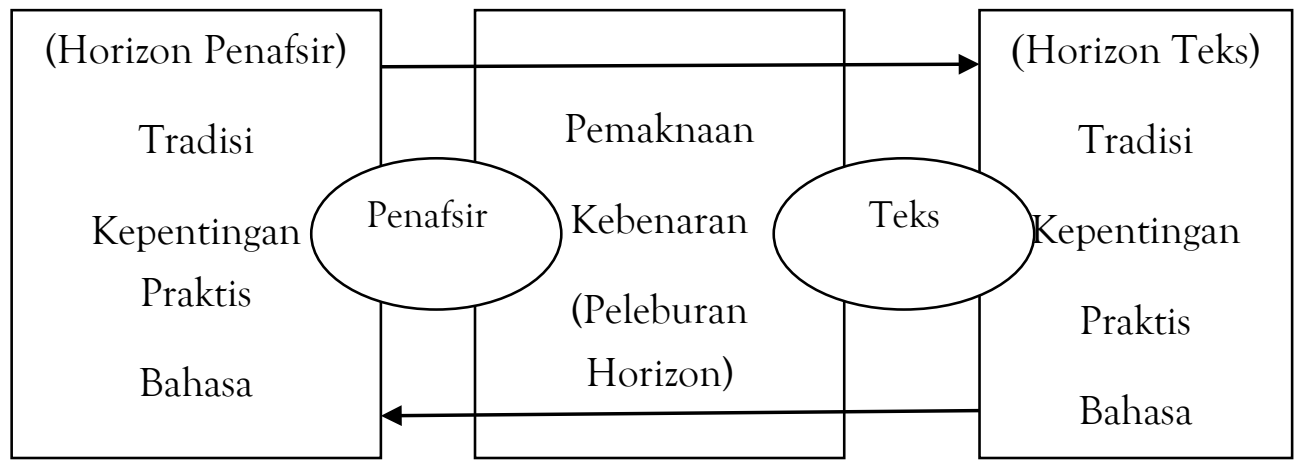

\section{Memahami Hadis “Keterlibatan Malaikat dalam Hubungan Seksual”: Sebuah Aplikasi Hermeneutika Gadamer}

Untuk menguji kerelevansian konsep hermeneutika Gadamer dan bagaimana kontribusinya dalam pengembangan studi keislaman, dalam bagian ini, konsep tersebut diaplikasikan untuk memahami hadis. Adapun hadis yang dipakai adalah hadis tentang keterlibatan malaikat dalam hubungan seksual. Kenapa hadis ini yang dipilih? Karena dalam pemahamannya, untuk masa sekarang, mengandung pemahaman yang bias gender. Dalam artian kepentingan yang ada dalam masa sekarang belum tercover dalam hadis ini, dan jika diaplikasikan apa adanya di masa sekarang maka akan meugikan kaum hawa. Dengan konsep yang ditawarkan Gadamer, terutama permasalahan horizon pembaca dan penerapa Meaningful sense, akan dilihat apakah pemahaman terhadap hadis ini akan tetap

\footnotetext{
${ }^{28}$ Sahiron Syamsuddin, Hermeneutika dan Pengembangan Ulumul Qur'an, h. 52.
} 
bias gender atau akan dihasilkan pemahaman yang berbeda.

\section{Teks dan Otentisitas Hadis}

Sebelum konsep Gadamer diaplikasikan dalam hadis ini, sebelumnya perlu diketahui keotentikan dari hadis ini. Satu-satunya teks hadis yang membahas tentang keterlibatan malaikat dalam hubungan seksual adalah hadis tentang apabila suami menginginkan di tempat tidur, tetapi sang istri tidak mau melayaninya dan membuat suaminya marah, maka para malaikat melaknatinya sampai pagi. Berikut adalah teks dari hadis tersebut

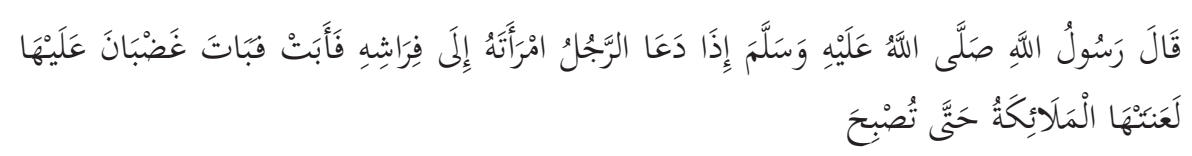

Rasulullah berkata "Apabila seorang suami mengajak istrinya ke tempat tidurnya, kemudia si istri enggan memebuhi ajakannya, sehingga suami merasa kecewa hingga tertidur, maka sepanjang malam itu pula para malaikat akan melaknat istri itu hingga datangnya waktu subuh"

Setelah dilakukan takhrij al-hadis dalam kutubut tis'ah, hadis yang menjelaskan tentang bid'ah memiliki lima jalur ${ }^{29}$, yaitu

Jalur pertama adalah riwayat Bukhari no. 3065. ${ }^{30}$ Dalam jalur ini terdapat enam perawi; 1) Abu Hurairah dinilai sebagai sahabat, 2) Abu Hazim dinilai tsiqah, 3) Al-A'masy dinilai tsiqah hafidz, 4) Abu 'Awanah dinilai tsiqah tsabat, 5) Musaddad dinilai tsiqah hafidz, 6) Bukhari dinilai min al-a'immah wa huffadz al-hadits.

Jalur kedua adalah riwayat Muslim no. 1436. ${ }^{31}$ Dalam jalur ini terdapat sepuluh perawi; perawi 1), 2), dan 3) sama dengan perawi dalam jalur pertama, 4) Jarir dinilai tsiqah, 5) Zuhair dinilai tsiqah tsabat, 6) Waqi' dinilai tsiqah hafidz

${ }^{29}$ Takhrij dan penelitian hadis dilakukan melalui CD-ROM Gawami' al-Kalim Hushn ad Difa' al-Awwal 'an as-Sunnah, Al-Idarah al-'Ammah li al-Auqaf dan Mausu'ah al-Hadits asy-Syarif.

${ }^{30}$ Muhammad ibn Isma'il al-Bukhari, Shahih Bukhari (Beirut: Daru Ibn Katsir, 1987), Juz 3, h. 1182.

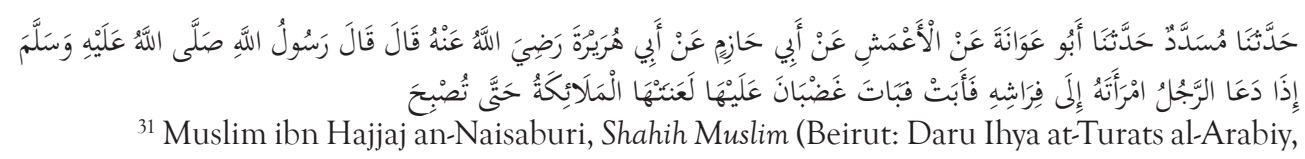
tt), Juz 2, h. 1060

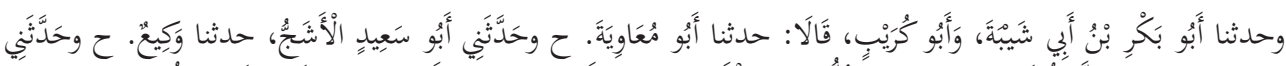

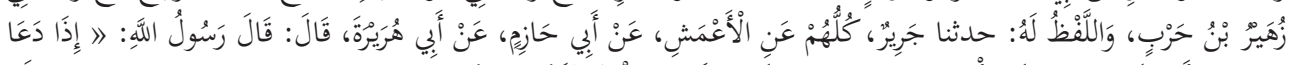

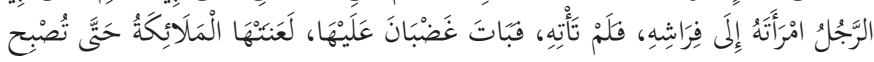


Millatī, Journal of Islamic Studies and Humanities, Vol. 3, No. 2, Des. 2018: 277-299

imam, 7) Abu Sa'id dinilai tsiqah, 8) Abu Mu'awiyah dinilai tsiqah, 9) Abu Karib dinilai tsiqah hafidz, 10) Muslim dinilai min al-a'immah wa huffadz al-hadits.

Jalur ketiga adalah riwayat Abu Dawud no. 2141.32 Dalam jalar ini terdapat enam perawi; perawi 1), 2), 3), dan 4) sama dengan perawi dalam jalur kedua, 5) ar-Razi dinilai tsiqah, 6) Abu Dawud dinilai tsiqah.

Jalur keempat adalah riwayat Ahmad no. 9379. ${ }^{33}$ Dalam jalur tersebut terdapat enam perawi; perawi 1) 2) dan 3) sama dengan perawi dalam jalur pertama, 4) Waqi' dinilai tsiqah hafidz imam, 5) Ibn Numair dinilai tsiqah, 6) Ahmad ibn Hanbal dinilai tsiqah.

Jalur kelima adalah riwayat Bukhari no. 4897. ${ }^{34}$ Dalam jalur tersebut terdapat tujuh perawi; perawi 1) dan 2) sama dengan perawi dalam jalur pertama, 3) Sulaiman dinilai tsiqah hafiidz, 4) Syu'bah dinilai tsiqah hafidz mutqin tsabit, 5) Ibn Abi 'Addi dinilai tsiqah, 6) Muhammad ibn Basyar dinilai tsiqah hafidz, 7) Bukhari dinilai min al-a'immah wa huffadz al-hadits.

Jalur keenam adalah riwayat Bukhari no. 1622. ${ }^{35}$ dalam jalur ini terdapat enam perawi; perawi 1) sama dengan perawi dalam jalur pertama, 2) Zurarah dinilai tsiqah, 3) Qatadah dinilai tsiqah tsabat, 4) Syu'bah dinilai tsiqah hafidz mutqin abid, 5) Muhammad ibn 'Ar'arah dinilai tsiqah, 6) Bukhari dinilai min al-a'immah wa huffadz al-hadits.

${ }^{32}$ Sulaiman ibn al-Asy'at as-Sijistani, Sunan Abu Dawud (tt: al-Maktabah al-'Isriyah, tt), juz 2, h. 244

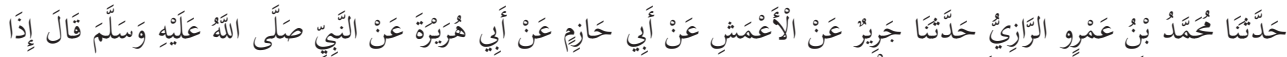

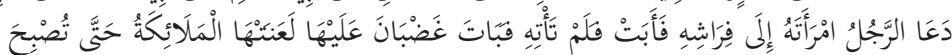

${ }^{33}$ Ahmad ibn Muhammad ibn Hanbal, Musnad Imam Ahmad (Mesir: Mu'assasah alQurthubi, tt), juz. 2, h. 439.

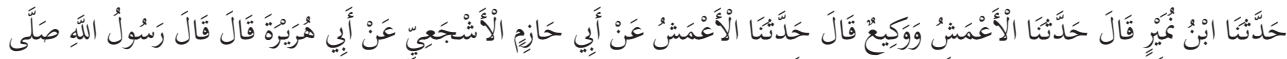

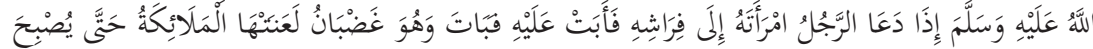

${ }^{34}$ Muhammad ibn Isma'il al-Bukhari, Shahih Bukhari.., Juz 5, h. 1993.

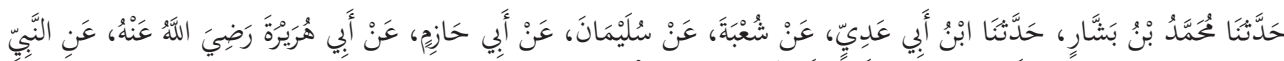

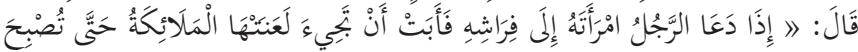

${ }^{35}$ Muhammad ibn Isma'il al-Bukhari, Shahih Bukhari ..., Juz. 5, h. 1994.

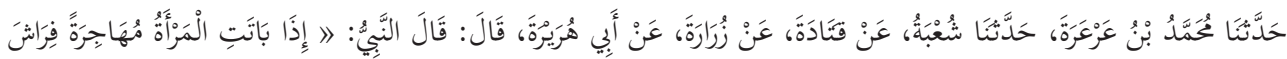

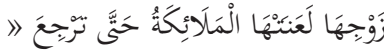


Jalur ketujuh adalah riwayat Muslim no. $1436 .{ }^{36}$ Dalam jalur ini terdapat tujuh perawi; perawi 1), 2), 3), dan 4) sama dengan perawi dalam jalur keenam, 5) Muhammad ibn Ja'far dinilai tsiqah, 6) Ibn Basyar dinilai tsiqah hafidz, 7) Muslim dinilai min al-a'immah wa huffadz al-hadits.

Jalur kedelapan adalah riwayat Muslim no. $1436 .{ }^{37}$ Dalam jalur ini terdapat tujuh perawi; perawi 1), 2), 3), 4), dan 5) sama dengan perawi dalam jalur ketujuh, 6) Muhammad ibn al-Mutsanna dinilai tsiqah tsabat, 7) Muslim dinilai min ala'immah wa huffadz al-hadits.

Jalur kesembilan adalah riwayat Ahmad no. 7422. ${ }^{38}$ Dalam jalur tersebut terdapat delapan perawi; perawi 1), 2), 3), 4), dan 5) sama dengan perawi dalam jalur ketujuh, 6) Syu'bah dinilai tsiqah, 7) Yazid dinilai tsiqah, 8) Ahmad dinilai tsiqah.

Jalur kesepuluh adalah riwayat Ahmad no. 8786. ${ }^{39}$ Dalam jalur tersebut terdapat enam jalur; perawi 1), 2), 3), dan 4) sama dengan perawi dalam jalur keenam, 5) Bahr dinilai tsiqah tsabat, 6) Ahmad dinilai tsiqah.

Jalur kesebelas adalah riwayat Ahmad no. 8373..$^{40}$ Dalam jalur tersebut terdapat enam perawi; perawi 1), 2), dan 3) sama dengan perawi dalam jalur keenam, 4) Hammam dinilai tsiqah, 5) 'Affan dinilai tsiqah, 6) Ahmad ibn Hanbal dinilai tsiqah.

${ }^{36}$ Muslim ibn Hajjaj an-Naisaburi, Shahih Muslim..., Juz 4, h. 112.

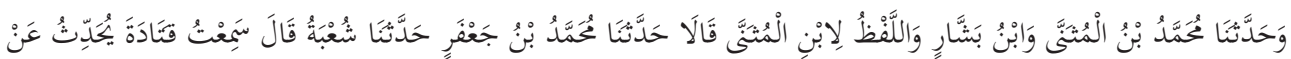

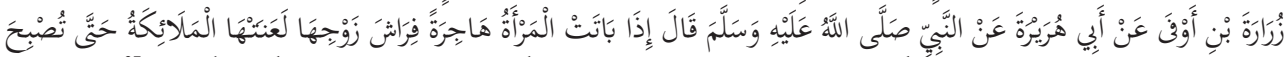

${ }^{37}$ Muslim ibn Hajjaj an-Naisaburi, Shahih Muslim..., juz 2 h. 1060

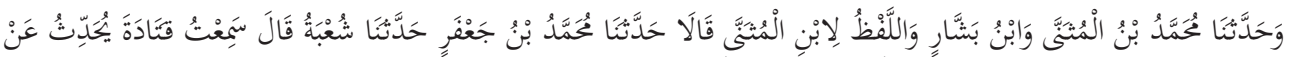

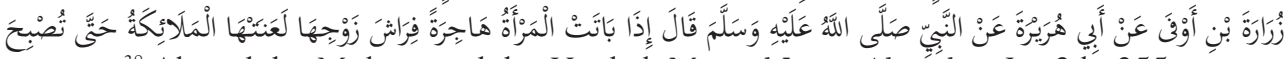

${ }^{38}$ Ahmad ibn Muhammad ibn Hanbal, Musnad Imam Ahmäd ..., Juz 2 h. 255

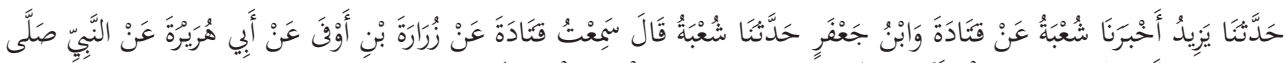

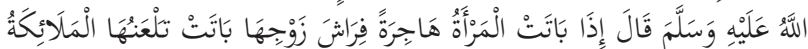

${ }^{39}$ Ahmad ibn Muhammad ibn Hanbal, Musnad Imam Ahmad ..., Juz. 2, h. 386.

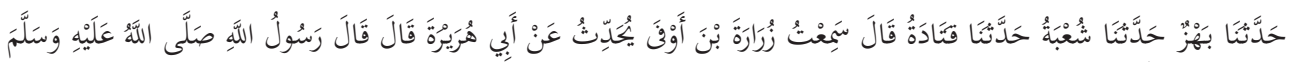

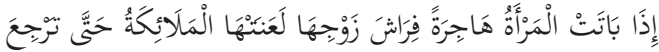

${ }^{40}$ Ahmad ibn Muhammad ibn Hanbal, Musnad Imam Ahmad ..., Juz. 2, h. 348.

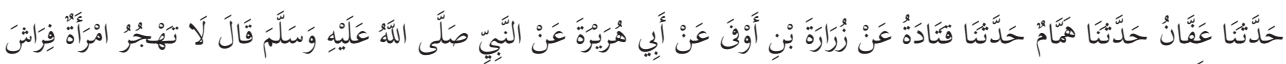

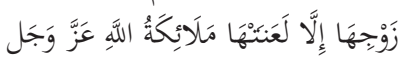


Millatī, Journal of Islamic Studies and Humanities, Vol. 3, No. 2, Des. 2018: 277-299

Berikut gambaran sanad hadis, setelah dilakukan I'tibar as-sanad,

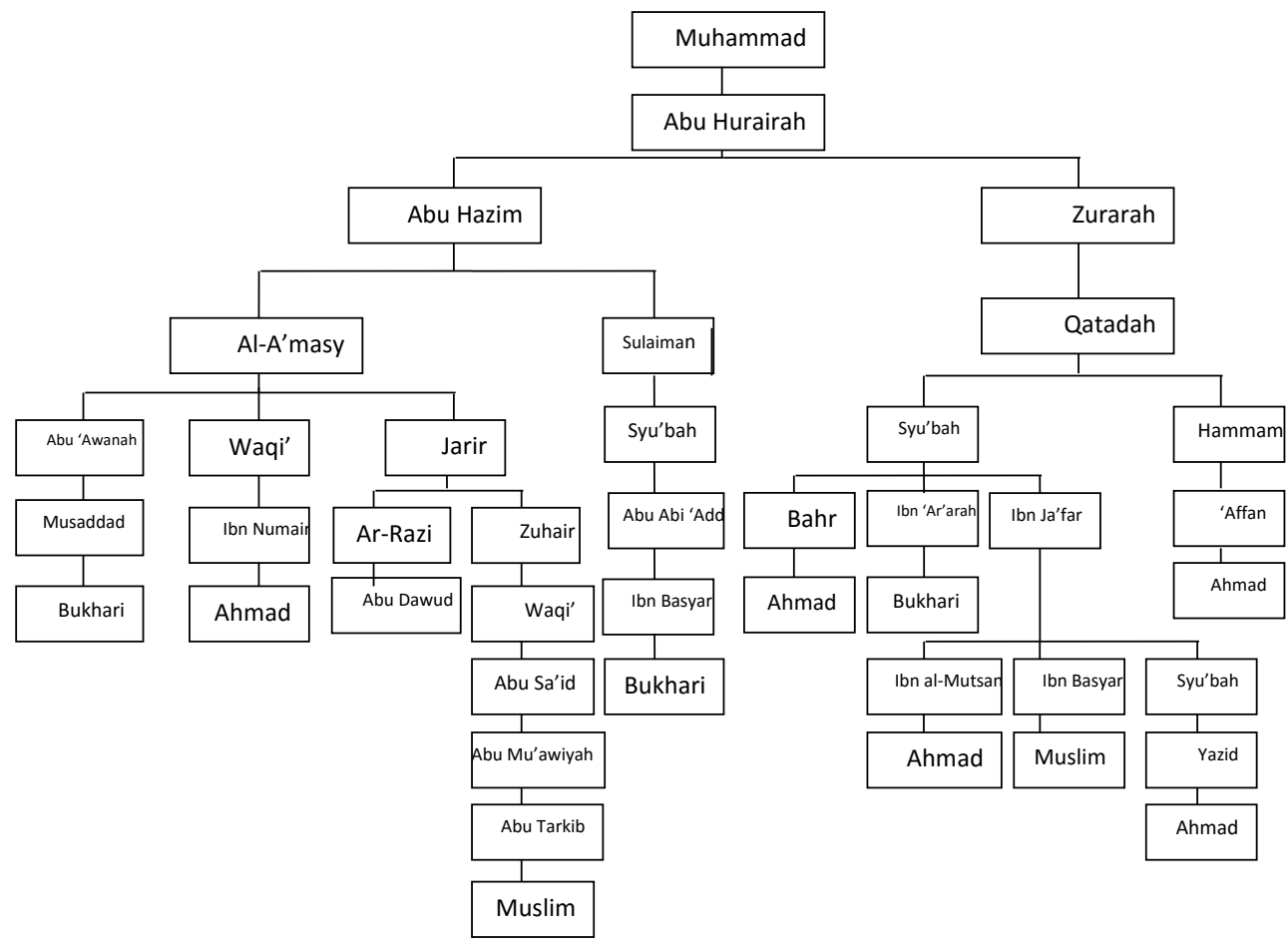

Dari sini dapat dilihat bahwa dari segi sanad, hadis ini memiliki kualitas shahih. Dalam artian tidak ditemukan perawi yang memiliki cacat, dan ditemukan ketersambungan sanad, disamping hadis ini masuk dalam muttafaq 'alaih (shahih menurut Bukhari dan Muslim). Namun dari segi kuantitas, hadis ini termasuk dalam kategori ahad, tepatnya adalah gharib, karena dalam jalurnya ditemukan rawi yang menyendiri, yaitu dalam tingkat sahabat Abu Hurairah (mengikuti pendapat ulama kullu sahabah 'udul, dan menghindari kontroversi Abu Hurairah sebagai perawi hadis). Mengikuti pendapat mayoritas ulama, hadis ini dapat diterima dari segi sanadnya. Untuk itu bisa dilakukan pemahaman dalam matannya, dengan menggunakan konsep hermeneutika Gadamer sebagai pendekatannya.

\section{Peleburan Horizon dan Menemukan Meaningful sense}

\section{Horizon Teks}

Horizon teks adalah tradisi atau kesejarahan (kepentingan, praktis, bahasa, budaya, situasi) yang meliputi teks. Dalam konteks hadis, tradisi ulama menyebutnya dengan asbab al-wurud baik mikro (situasi khusus yang menyebabkan 
hadis ada) atau makro (situasi sosial-historis zaman Nabi). Dan tidak semua hadis ditemukan asbab al-wurud mikrao, bukan karena tidak ada tapi tidak tercantum atau terekam oleh sejarah tradisi Islam klasik. Hadis tentang keterlibatan malaikat dalam hubungan seksual, tidak ditemukan asbab al-wurud mikronya. Meski demikian, bagaimana hadis ini terbentuk pasti tidak terlepas dari kondisi sosialhistoris ketika itu (asbab al-wurud makro).

Hadis ini kemungkinan berkaitan erat dengan budaya Ghilah pada masa pra-Islam. Ghilah adalah menggauli istri yang sedang hamil atau menyusui. Bagi masyarakat pra-Islam, Ghilah adalah sesuatu yang sangat tabu dan pantan untuk dilakukan, bahkan sangat melekat kuat dalam budaya mereka. ${ }^{41}$ Namun, hal tersebut bukan menjadi persoalan bagi kaum laki-laki, karena poligami pada masa itu tidak ada batasnya. Jika ada istri yang sedang hamil atau menyusui, masih ada cadangan istri lainnya.

Ketika Islam datang dengan ajarannya, terutama untuk mengangkat derajat wanita, poligami mulai dibatasi. Dalam kondisi inilah para laki-laki Arab menghadapi berbagai kesulitan-kesulitan ketika menemui istri-istri mereka yang sedang hamil atau menysusui. Sehingga setelah diketahui bahwa Ghilah tidak menimbulkan bahaya bagi anak-anak yang dilahirkan, Nabi mengurungkan untuk melarang perbuatan Ghilah. Namun tetap saja, karena budaya ini sudah terlanjur melekat pada diri wanita masa itu, ada wanita yang menolak ajakan suaminya untuk bersetubuh, di damping poligami telah dibatasi. ${ }^{42}$ Karena khawatir akan menimbulkan permasalahan dalam hubungan suami-istri, seperti perceraian, perzinaan, dan lain-lain, maka dimungkinkan hadis ini muncul untuk mengatasi kesulitan-kesulitan tersebut yang dirasakan para laki-laki Arab ketika itu. Maka oleh karenanya hadis ini harus dipahami sebagaibentuk usaha dari Nabi untuk mempertahankan atau melanggengkan hubungan suami-istri ketika itu, yang jika istri menolak karena alasan Ghilah_padahal Ghilah tidak menimbulkan bahaya bagi anaknya_akan menimbulkan kesulitan bagi suaminya, bukan sekedar pelaknatan malaikat kepada istri yang menolak ajakan suaminya.

Perlu dilihat pula bagaimana posisi wanita ketika itu juga perlu dipertimbangkan. Pada masa pra-Islam, wanita boleh diperjual-belikan, dan yang sudah berumah tangga sepenuhnya menjadi miliki suami dan mutlak harus tunduk di bawah kekuasaan suami. Mereka tidak memiliki hak sipil, bahkan hak

${ }^{41}$ Hamim Ilyas dkk. Perempuan Tertindas: Kajian Hadis-hadis Misoginis, (Yogyakarya: Elsaq Press, 2003), h. 215.

${ }^{42}$ Hamim Ilyas dkk. Perempuan Tertindas, h. 215. 
Millatī, Journal of Islamic Studies and Humanities, Vol. 3, No. 2, Des. 2018: 277-299

warispun tidak dipunyai, yang ada justru merekalah yang diwariskan. Perempuan menjadi kebutuhan syahwat dan kemewahan bagi laki-laki. Sebelum menikah wanita berada di bawah kekuasaan ayahnya, dan ketika menikah beralih kepada kekuasaan laki-laki. Kekuasaan itu mencakup kewenangan menjual, mengusir, menganiaya, dan membunuh. Konsekuwensi dari ini poligami adalah hal yang lumrah, dan tidak ada batasannya. ${ }^{43}$

Setelah Islam datang, poligami dibatasi dan tersusun dalam aturannya sendiri. Namun, bagaimanapun budaya patriarkhi masih melekat pada kebudayaan Arab, dan menghapus seluruhnya adalah sesuatu yang susah. Di sisi lain Islam juga mengatur hubungan hak dan kewajiban suami-istri, yang tidak ditemukan dalam tradisi sebelum Islam. Ada beberapa hadis yang menjelaskan tentang kewajiban suami-suami atas istri mereka, meski istri tetap masih dalam taraf pemuas bagi laki-laki. Tapi apa yang dilakukan Islam ini mengindikasikan sebuah proses untuk keluar dari jerat-jerat bias gender pra-Islam. Seperti adanya hadis diperbolehkan mendatangai ladang lelaki (wanita) sesukanya, tapi dilarang memukulnya. ${ }^{44}$ Adanya larangan memukul istrinya menunjukkan bahwa ada usaha dari Nabi untuk menjauhkan perempuan dari kekerasan dan kebiasan yang sebelumnya menjadi hal yang lumrah. Selain itu dalam hadis lain dijelaskan kewajiban suami untuk memberikan nafkah, yang berupa makanan, pakaian, bahkan dilarang memukul wajah dan menjelekkannya. ${ }^{45}$ Bahkan, mengasuh anak mulai dari kandungan dampai menikah adalah tugas suami. Dalam suatu ayat (QS. ath-Thalaq: 6) ${ }^{46}$ dijelaskan bahwa ketika dalam masa iddah pun ketika istri mengandung maka tetap wajib menafkahinya sampai mereka melahirkan. Jika mereka menyusui anak, maka ada perintah memberikan upah kepadanya. Dalam urusan dapurpun para istri banyak yang dibantu oleh para budak. Maka

${ }^{43}$ Al-Hamid al-Husaini, Baitun Nubuwwah: Rumah Tangga Nabi Muhammad (Bandung: Yayasan al-Hamidiy, 1997), h. 14.

${ }^{44}$ Abu Dawud no. 2143.

عن جدي قال قلت ثم يا رسول الله نساؤنا ما نأتي منهن وما نذر قال ائت حرثك أنى شئت وأطعمها إذا طعمت واكسها

${ }^{45}$ Abu Dawud no. 2142.

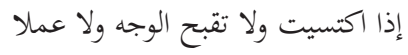

عن حكيم بن معاوية القشيري عن أبيه قال قلت ثم يا رسول الله ما حق زوجة أحدنا عليه قال أن تطعمها إذ طعمت وتكسوها

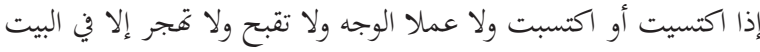

${ }^{46}$ QS. Ath-Thalaq (65) : 6.

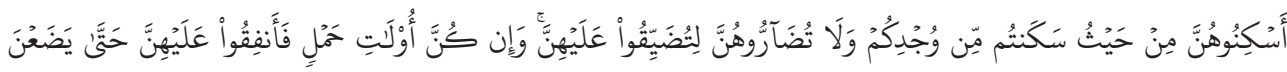

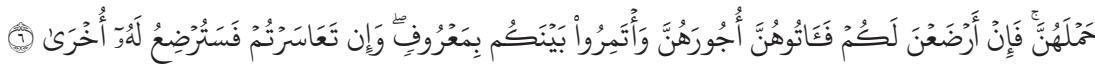


bagaimana hadis ini muncul adalah suatu yang sangat sesuai dengan kondisi ketika itu, yaitu di saat poligami dibatasi, kewajiban suami dipertegas, para istri semakin dipermudah dan diangkat kedudukannya, sedang para suami belum mampu menghilangkan kebiasaan pra-jahiliyah (istri menjadi objek), maka penekanan untuk keharusan istri memenuhi kebutuhan seksual suami sangat wajar.

Selain itu, ketika hadis tersebut hanya dipahami apa adanya, maka akan menafikan realitas kebutuhan seks bagi seorang istri. Padahal Nabi tidak hanya menekankan kebutuhan seks bagi seorang suami, tapi bagaimana hak istri harus dipenuhi juga menjadi anjuran Nabi. ${ }^{47}$ Sebagaimana dapat dilihat dalam hadis tentang larangan Nabi kepada Abdullah ibn Umar ibn 'Ash untuk puasa terus menurus, karena akan mengabaikan hak-hak yang lainnya, termasuk hak istrinya.

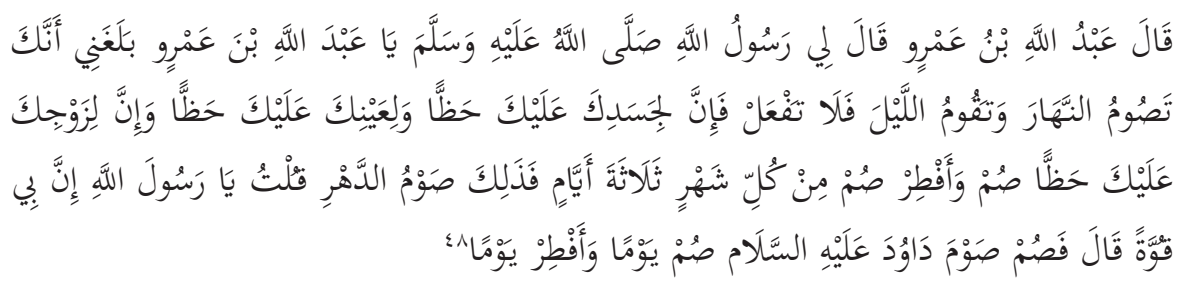

Telah berkata Abdullah ibn 'Umar ibn 'Ash, Rasulullah telah berkata kepadaku, wahai Abdullah ibn Umar telah sampai kepadaku bahwasanya engkau puasa di siang hari dan shalat di malam hari. Janganlah kamu melakukan seperti itu. Sesungguhnya bagi jasadmu, matamu, istrimu memiliki hak atasmu. Berpuasalah dan berbukalah tiga hari dalam sebulan. Berpuasa dahr akan memberatkan semuanya. Kemudian saya berkata, wahai Rasul saya kuat lebih dari itu. Nabi menjawab puasalah seperti puasa Nabi dawud, sehari berpuasa dan sehari berbuka.

Selain itu juga ditemukan hadis riwayat Abu Dawud yang menunjukkan perintah menikahi seorang gadis, agar dapat bercengkrama dengannya, sebagaimanapun sebaliknya, agar gadis tersebut juga dapat bercengkrama dengan suaminya.

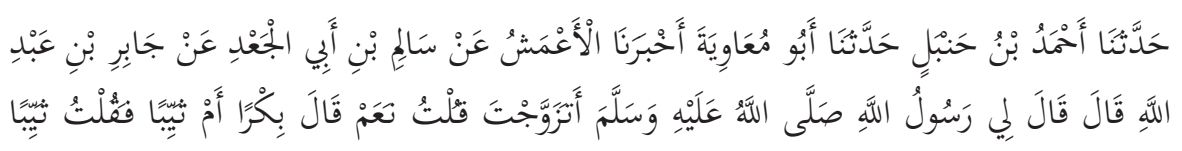

${ }^{47}$ Nurun Najwah, "Otonomi Perempuan dalam Keluarga" dalam Islam, Tradisi, dan Peradaban, ed. Sahiron Syamsudin (Yogyakarta: Bina Mulia Press, 2012), h. 191.

${ }^{48}$ Muslim ibn Hajjaj an-Naisaburi, Shahih Muslim..., juz 2, h. 818. 
Millatī, Journal of Islamic Studies and Humanities, Vol. 3, No. 2, Des. 2018: 277-299

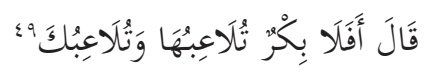

Dari Jabir ibn Abdullah berkata, Rasulullah telah berkata kepadaku 'Apakah kamu akan menikah?' 'Benar' jawabku, Nabi berkata 'Gadis atau janda?', maka aku jawab 'Janda'. Nabipun berkata, 'Mengapa tidak gadis?, engkau dapat bercengkerama dengannya, diapun dapat bercengkerama denganmu”.

Terdapat juga hadis yang menekankan seorang suami meminta izin kepada istrinya ketika hendak 'azl, yaitu

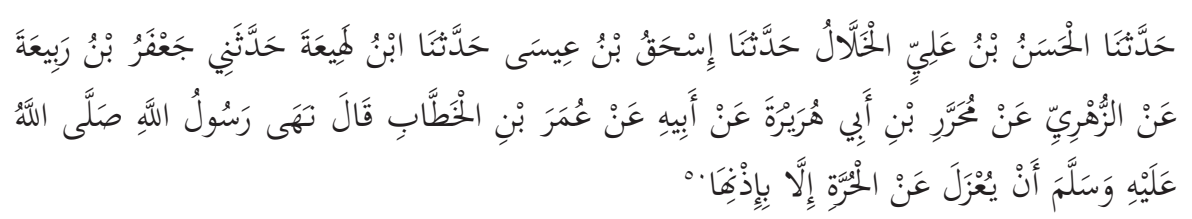

"Dari Umar ibn Khattab berkata, Rasulullah telah melarang melakukan 'azl terhadap perempuan merdeka, kecuali atas izinnya”.

Ketiga hadis yang disebutkan tersebut menunjukkan bahwa istripun memiliki hak seksual sebagaimana suami. Pemahaman hadis tentang keterlibatan malaikat, hanya akan memonopoli istri yang sebenarnya juga memiliki hak yang sama dengan suami. Untuk itu perlu dipahami bahwa maksud Nabi berkata demikian adalah karena untuk menjaga keharmonisa hubungan suami-istri. Jadi jika yang terjadi sebaliknya, dalam artian penolakan suami yang juga akan menimbulkan rusaknya hubungan suami-istri, maka suamipun juga berhak mendapatkan pelaknatan perempuan.

Dari segi bahasa juga harus diperhatikan. Untuk menganalisis bentuk bahasa yang dipakai sebaik juga diperhatikan teks lain yang se-zaman, dan alQur'anlah dianggap mampu mewakilinya. Kata pertama yang dipertanyakan pemaknaannya adalah kata da'a. Dalam al-Qur'an kata ini dapat ditemukan dalam QS. an-Nahl: 125. Al-Qurthubi menjelaskan da'a sebagai kegiatan mengajak ke jalan Allah dengan cara lemah lembut dan sopan, bukan dengan pemaksaan dan kasar. ${ }^{51}$ Dalam tafsir as-Sa'di ajakan tersebut didasarkan atas

\footnotetext{
${ }^{49}$ Sulaiman ibn al-Asy'at as-Sijistani, Sunan Abu Dawud ..., juz. 2 h. 220

${ }^{50}$ Muhammad ibn Yazid al-Quzwaini, Sunan ibn Majjah (tt: Maktabah al-'Alamiyah, tt), Juz. 1, h. 620 .

${ }^{51}$ Muhammad ibn Ahmad ibn Abi Bakar al-Qurthubi, Tafsir al-Qurthubi (Kairo: Dar asy-Sya'bi, 1372 H), Juz. 10, h, 201.

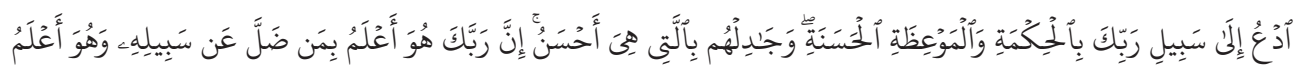


pengetahuan, jika dikaitkan dalam hadis ini adalah pengetahuan terhadap kondisi istri. ${ }^{52}$ Penggunaan kata penolakan istri adalah kata $b a$ 'a. Dalam al-Qur'an kata tersebut dapat ditemukan dalam kasus penolakan iblis untuk sujud kepada Adam (QS. al-Baqarah: 34$).{ }^{53}$ Jadi penolakan yang dilakukan adalah penolakan yang keras dan disertai dengan keangkuhan atau kesombongan. Bisa jadi pula pelaknatan ini berlaku bagi istri yang menolak, dengan tolakan yang tidak sopan dan kondisinya tidak mengharuskan untuk menolak ajakan suami yang lemah lembut, penih kesopanan dan mengatahui betul kondisi istrinya.

\section{Horizon Pembaca}

Abad ke-21 memperlihatkan berbagai perubahan yang drastis di semua wilayah masyarakat Muslim, termasuk wilayah peran perempuan. Dimulai pada ertengahan tahun 1960, perempuan membawa isu-isu baru terkait: kesamaan besaran upah dengan laki-laki; dihilangkannya diskriminasi atas dasar seks, ras, agama, warna kulit, serta asal daerah; dibebaskannya perempuan untuk melakukan aktifitas di luar rumah tidak hanya dituntut menjadi be a good wifes and mothers; serta kesamaan perempuan dengan laki-laki dalam bidang pendidikan, pekerjaan, politik (kesempatan untuk dipilih), bahkan di dalam rumah tangga. Pada saat itu perempuan tidak hanya mengkritisi supremasi lakilaki di masyarakat, tetapi perempuan mulai bereksperimen dengan tubuhnya. ${ }^{54}$

Sekarang isu-isu itu telah nyata. Kaum perempuan memiliki akses kepada pendidikan, sebagaimana laki-laki, dan juga memiliki kesempatan yang lebih besar untuk bekerja. Di banyak negara perempuan telah mampu menduduki jabatan publik. Tidak hanya itu, di dalam rumah tangga pekerjaan-pekerjaan domestik telah dikerjakan bersama-sama antara suami dan istri di banyak negara. ${ }^{55}$ Oleh karenanya perempuan bisa berbagi peran dengan kaum laki-laki, termasuk dalam keluarga. Bagaimana permasalahan nafkah, bahkan ditanggung

${ }^{52}$ Mausu'atul Qur'anil Karim dalam www.islamspirit.com

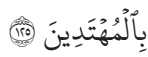

${ }^{53}$ Mausu'atul Qur'anil Karim dalam www.islamspirit.com

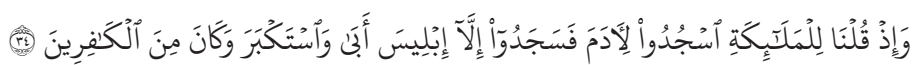

${ }^{54}$ Yuliana Riana P dan Hedi Pudjo Santoso, "Faktor-faktor yang Berpengaruh terhadap Pandangan Postfeminisme melalui Pemaknaan atas Representasi Perempuan dengan Sexual Appearance di dalam Iklan” dalam Beyond Borders: Communication Modernity and History (Jakarta: STIKOM, 2010), h. 50.

55 Syakwan Lubis "Gerakan Feminisme dalam Era Postmodernisme Abad 21" dalam DEMOKRASI Vol. V No. 1 Th. 2006. 
Millatī, Journal of Islamic Studies and Humanities, Vol. 3, No. 2, Des. 2018: 277-299

oleh kedua belah pihak, dan tidak hanya ada pada suami. Jikapun istri tidak bekerja, mereka dengan suka rela mengurus urusan keluarga dan anaknya, bahkan tanpa dibayarpun.

Harus diakui bahwa peranan kaum wanita dalam abad saat ini amatlah menonjol. Banyak posisi yang tadinya didominasi kaum pria sekarang sudah mulai beralih dan diduduki oleh kaum wanita. Hal ini tidak hanya terjadi di negara-negara sangat maju, tapi juga di negara-negara industri baru, dan bahkan di negara-negara berkembang. Perempuan memiliki peran dan fungsi yang sangat strategis dalam keluarga dan masyarakat. ${ }^{56}$

Permasalahan kesetaraan ini sampailah kepada permasalahan seksual, yang perempuan seharusnya tidak hanya sekedar menjadi second seks. Jika tidak sampai kepada permasalahan ini, maka akan merusak hubungan antara suamiistri. Dalam tulisan Alimatul Qibtiyah disebutkan bahwa masalah perceraian 80\% disebabkan karena tidak puas dalam hubungan seksual. Selain itu, sebuah studi di Amerika Serikat menemukan bukti bahwa $80 \%$ pasangan yang mencari konseling perkawinan ternyata secara seksual mereka tidak terpuaskan. ${ }^{57}$

Dalam kasus ini yang terjadi adalah pemerkosaan dalam rumah tangga, atau pemerkosaan oleh suami kepada istri. Banyak istri terpaksa melayani suami, padahal ia dalam kondisi lemah dan letih karena pekerjaan domestik ataupun publik. Dalam kasus ini perkawinan dianggap sebagai legitimasi resmi kekuasaan laki-laki atas perempuan secara jiwa dan raga. Karena sifatnya yang otonom lakilaki bisa merasa berhak nyaris bisa melakukan apa saja. ${ }^{58}$

Sebuah perbuatan bisa dikategorikan pemerkosaan salah satunya apabila mengandung kekerasan. Pemerkosaan dalam rumah tangga nyatanyata melanggar hak istri karena seks adalah juga haknya. Hubungan seks yang dilakukan di bawah tekanan atau pemaksaan sama dan sebangun dengan penindasan. Apabila istri tidak menginginkan akannya, maka yang terjadi justru tersakiti secara fisik dan psikis. Seorang suami tidak boleh memaksa kehendak kepada istrinya, khususnya terkait perkara seksual. Jika tidak, maka yang terjadi bisa sampai kepada perceraian. ${ }^{59}$

${ }^{56}$ Syakwan Lubis "Gerakan Feminisme dalam Era Postmodernisme Abad 21" dalam DEMOKRASI Vol. V No. 1 Th. 2006.

${ }^{57}$ Hamim Ilyas dkk. Perempuan Tertindas, h. 213.

${ }^{58}$ Fathul Djannah dkk. Kekerasan terhadap Istri (Yogyakarta: LKis, 2002). h. 30.

${ }^{59}$ Milda Marlia, Marital Rape: Kekerasan Seksual terhadap Istri, (Yogyakarta: Pustaka Pesantren, 2007), h. 2. 


\section{Meaningful sense dalam Peleburan Horizon}

Setelah mengkaji bagaimana horizon teks dan horizon masa kini, selanjutnya dilakukan peleburan horizon guna mendapatkan Meaningful sense. Bagaimana hadis tersebut muncul relevan dengan historisitasnya, begitu pula dengan kebahasan yang digunakan hadis tersebut sangat sesuai dengan praktek yang seharusnya ketika itu. Karena bagaimanapun hadis itu muncul adalah untuk mengatasi kesulitan-kesulitan yang dihadapi kaum laki-laki ketika itu, setelah disyariatkannya poligami, untuk menghindari perceraian atau rusaknya hubungan keluarga. Di lain pihak peran istri ketika itu tidak begitu mendominasi, dibanding laki-laki yang bertanggung jawab penuh atas istrinya, termasuk masalah domestik dan mengurus anak.

Bagaimana praktek yang sebenarnya dapat dilihat melalui hadis-hadis lainnya, dan susunan bahasa yang digunakan. Sebagaimana yang telah dijelaskan sebelumnya, terdapat banyak hadis yang menjelaskan tentang perempuanpun berhak mendapatkan kebutuhan seks, tidak hanya laki-laki. Dari segi bahasa, pelaknatan berlaku bagi istri yang menolak dengan angkuh ( $\left.b a^{\prime} a\right)$ ajakan suaminya yang lemah lembut, sopan, dan mengetahui kondisi istrinya apakah dalam keadaan lelah, tidak siap, dan lain sebagainya atau tidak ( $\left.d a^{\prime} a\right)$.

Sedangkan yang terjadi di masa sekarang adalah berbeda. Istri bisa berbagi ruang dengan suami, tidak hanya di ranah publik, tapi juga domestik. Jika masalah seksualitas hanya berada di kekuasaan suami, maka yang terjadi adalah ketidak harmoniasan hubungan suami-istri. Bahkan banyak terjadi perceraian karena permasalahan yang seperti ini.

Padahal dalam Islam, prinsip pernikahan adalah sakinah, mawaddah, dan rahmah. Sehingga di sini dapat dipahami bahwa yang dimaksud oleh Nabi dalam hadis ini, atau Meaningful sense dari hadis pelaknatan malaikat kepada istri yang menolak hubungan seksual adalah "menjaga dan mempertahankan keharmonisan hubungan suami-istri”. Caranya adalah dengan menekankan kepada wa'asyiruhunna bil ma'ruf, menggauli dengan cara yang ma'ruf, yaitu dengan cara memahami keadaan dan kondisi pasangannya. Inilah yang menurut Gadamer yang seharusnya diterapkan dalam setiap zaman dan masa, yang mampu melampaui kepartikularan. 
Millatī, Journal of Islamic Studies and Humanities, Vol. 3, No. 2, Des. 2018: 277-299

\section{Kesimpulan}

Hermeneutika Gadamer sangat menekankan kepada penggabungan horizon, yang darinya akan diperoleh Meaningful sense. Meaningful sense inilah yang menurut Gadamer, dapat diterapkan di masa pembaca. Ketika teori hermeneutika Gadaner diaplikasikan dalam hadis "keterlibatan malaikat dalam hubungan seksual", Meaningful sense yang didapat adalah "menjaga dan mempertahankan keharmonisan hubungan suami-istri”. Sedangkan dalam penerapannya disesuaikan dengan kondisi pembaca, asalkan Meaningful sense dari hadis ini tetap ada, yaitu bisa dengan didasarkan atas kesepakatan antara kedua belah pihak atau antara suami dan istri. Sehingga konsep hermeneutika Gadamer dapat dikatakan relevan untuk menghilangkan isu yang berkembang dewasa ini, yaitu bias gender.

\section{Referensi}

Ahmalia dkk. Praksis Islamic Studies, ed. Nafisul Atho' dan Arif Fahrudin. Yogyakarta: IRCiSoD, 2003.

Bukhari, Muhammad ibn Isma'il. Shahih Bukhari. Beirut: Daru Ibn Katsir, 1987.

CD-ROM Gawami' al-Kalim Hushn ad Difa' al-Awwal 'an as-Sunnah, Al-Idarah al'Ammah li al-Auqaf.

Djannah, Fathul. dkk. Kekerasan terhadap Istri. Yogyakarta: LKis, 2002.

Gadamer, Hans-Georg. Kebenaran dan Metode, terj. Ahmad Sahidah. Yogyakarta: Pustaka Pelajar, 2010.

Halim,Abdul. Aswaja Politisi Nahdlatul Ulama: Perspektif Hermeneutika Gadamer. Jakarta: LP3ES, 2014.

Husaini, Al-Hamid. Baitun Nubuwwah: Rumah Tangga Nabi Muhammad. Bandung: Yayasan al-Hamidiy, 1997.

Hanbal, Ahmad ibn Muhammad ibn. Musnad Imam Ahmad. Mesir: Mu'assasah al-Qurthubi, tt.

Ilyas, Hamim. dkk. Perempuan Tertindas: Kajian Hadis-hadis Misoginis. Yogyakarya: Elsaq Press, 2003.

Lubis, Syakwan. "Gerakan Feminisme dalam Era Postmodernisme Abad 21" dalam DEMOKRASI Vol. V No. 1 Th. 2006.

Mausu'ah al-Hadits asy-Syarif. 
Marlia, Milda. Marital Rape: Kekerasan Seksual terhadap Istri. Yogyakarta: Pustaka Pesantren, 2007.

Mausu'atul Qur'anil Karim dalam www.islamspirit.com

Muzir, Inyiak Ridwan. Hermeneutika Filosofis Hans-Georg Gadamer. Yogyakarta: ar-Ruzz Media, 2010.

Naisaburi, Muslim ibn Hajjaj. Shahih Muslim. Beirut: Daru Ihya at-Turats alArabiy, tt.

Najwah,Nurun. "Otonomi Perempuan dalam Keluarga" dalam Islam, Tradisi, dan Peradaban.

Palmer, Richard E. Hermeneutika Teori Baru Mengenai Interpretasi, terj. Musnur Hery dan Damanhuri Muhammed. Yogyakarta: Pustaka Pelajar, 2005.

Quzwaini, Muhammad ibn Yazid. Sunan ibn Majjah. tt: Maktabah al-'Alamiyah, tt. Qurthubi, Muhammad ibn Ahmad ibn Abi Bakar Tafsir al-Qurthubi. Kairo: Dar asy-Sya'bi, $1372 \mathrm{H}$.

Riana, Yuliana dan Hedi Pudjo Santoso, "Faktor-faktor yang Berpengaruh terhadap Pandangan Postfeminisme melalui Pemaknaan atas Representasi Perempuan dengan Sexual Appearance di dalam Iklan” dalam Beyond Borders: Communication Modernity and History. Jakarta: STIKOM, 201.

Shihab, Quraisy. Kaidah Tafsir. Tangerang: Lentera Hati, 2013.

Sijistani, Sulaiman ibn al-Asy'at. Sunan Abu Dawud. tt: al-Maktabah al-'Isriyah, tt.

Syamsuddin, Sahiron. Hermeneutika dan Pengembangan Ulumul Qur'an. Yogyakarta: Pesantren Nawesea Press, 2009.

Zayd, Nasr Hamid Abu. Al Quran Hermeneutik dan Kekuasaan, terj. Dede Iswadi, Jajang Rahmana, dan Ali Mursyid. Jakarta: Rais, 2003. 